\title{
Contraceptive practices of Brazilian adolescents: social vulnerability in question
}

\author{
Práticas contraceptivas de adolescentes brasileiras: \\ vulnerabilidade social em questão
}

Riva Rozenberg ${ }^{1}$

Katia Silveira da Silva ${ }^{1}$

Claudia Bonan ${ }^{1}$

Eloane Gonçalves Ramos ${ }^{1}$
${ }^{1}$ Instituto Fernandes Figueira, Fiocruz. Av. Rui Barbosa 716, Flamengo 22.250-020 Rio de Janeiro RJ Brasil.

rivarozen@gmail.com
Abstract This article seeks to analyze contraceptive practices of Brazilian adolescents and to discuss associated vulnerability situations. A crosssectional study was conducted, using the database of the National Survey on Demography and Health of Women and Children - PNDS 2006. Factors associated with the current use of contraceptive methods were investigated. The analysis included 986 sexually-active adolescents. Bivariate analysis between the outcome and each of the socioeconomic, demographic and reproductive characteristics of women was performed. The associations between variables were evaluated using multivariate logistic regression. Four factors related to outcome were identified in the multivariate analysis: having completed junior high school ( $a O R=2.29$; CI 95\% 1.07-4.85); being married or cohabiting with a partner ( $a O R=2.85$; CI 95\% 1.45-5.59); having used contraceptives during the first sexual intercourse ( $a O R=2.77$; CI 95\% 1.36-5.63); and having access to transportation to get to health center services $(a O R=3.33$; CI 95\% 1.42-7.80). Adolescents with higher social vulnerability are at a disadvantage regarding adoption of contraceptive methods. This points to the need to establish intersectoral articulations of public policies, which could ensure their reproductive rights.

Key words Contraception, Adolescence, Contraceptive behavior, Vulnerability, Health services
Resumo O objetivo deste estudo é analisar práticas contraceptivas de adolescentes brasileiras e discutir situações associadas de vulnerabilidade. Estudo transversal, utilizando banco de dados da Pesquisa Nacional de Demografia e Saúde da Criança e da Mulher (PNDS) 2006. Foram investigados fatores associados ao uso atual de métodos anticoncepcionais. A análise incluiu 986 adolescentes sexualmente ativas. Foi realizada análise bivariada entre desfecho e cada variável independente. Associações entre variáveis foram avaliadas pela regressão logística multivariada. O nível de significância foi de 0,05. Na análise multivariada identificamos quatro fatores associados ao desfecho: ter no mínimo o ensino fundamental completo ( $p=$ 0,03; $O R_{\text {ajustado }}=2,17 ;$ IC 95\% 1,03-4,55); união estável ( $p<0,01 ; \mathrm{OR}_{\text {aiustado }}=2,84$; IC 95\% 1,455,54); uso de método anticoncepcional na primeira relação sexual $\left(p<0,01 ; O R_{\text {ajustado }}=2,72 ; I C\right.$ 95\% 1,37-5,42); e acesso a transporte para chegar ao serviço de saúde $\left(p<0,01 ; O R_{\text {ajustado }}=2,90 ;\right.$ IC 95\% 1,32-6,36). Adolescentes com maior vulnerabilidade social utilizam menos métodos anticoncepcionais. Isto aponta para a necessidade de estabelecer articulações intersetoriais com politicas públicas que garantam os direitos reprodutivos de adolescentes.

Palavras-chave Anticoncepção, Adolescência, Comportamento contraceptivo, Vulnerabilidade, Serviços de saúde 


\section{Introduction}

In Brazil, during the second half of the 20th century, the demographic transition was accelerated with the decrease of general mortality, fertility rates and populational growth and the increase of life expectancy and transformations in the age pyramid. In the 1990s, births were concentrated in younger age groups, and there were changes in juvenile behavior, such as an earlier sexual initiation without marital strains. In this context, sexuality and pregnancy in adolescence gained greater visibility and became the focus of debates and controversies in the areas of public policies, academic scenario and in society in general.

Brazil is a large country, with socioeconomic and regional disparities undergoing fast economic, social, and environmental changes. The country's population is of 194.9 million $^{1}$, and its $\mathrm{Hu}-$ man Development Index (HDI) is 0.718 (United Nation Development Program, 2011). In regards to health assistance, since 1988 , the country depends on/reckons upon the Unified Health System, a system of universal access to health sponsored mainly by the federal government, composed of public and private. In the 1990s, the Family Health Strategy expanded primary health assistance to regions that were poorer and more distant from urban centers. In 2009the coverage of the Family Health Strategy reached 50,7\% of the Brazilian population².

With the implementation of several studies we have seen that the interest in contraception has grown ${ }^{3-5}$. Contraceptive practices in adolescence involve complex relational and contextual aspects and the heterogeneity of their experiences leads to different levels of protection according to their biographic and social characteristics ${ }^{3}$. The persistence of social and gender inequalities, that is, differentiated access to health services, quality in education, and difficulty in negotiating with partners, stresses the vulnerability of adolescents in the adoption of contraceptive practices ${ }^{5,6}$.

In this study, the contraceptive practices of Brazilian adolescents were analyzed based on the data of the National Survey on Demography and Health of Women and Children - PNDS 2006 Brazil ${ }^{7}$. The objective was to identify factors associated to the use of contraceptive methods, including social-demographic characteristics connected to their sexual and reproductive lives, social vulnerability, and their impact on contraceptive practices of Brazilian adolescents.

\section{Materials and methods}

\section{Design and Data Source}

This was a cross-sectional study with information on Brazilian women and families obtained from the PNDS-2006 database, which was available to the public. PNDS-2006 is a home research of complex probability sampling with national representability, which had among its objectives to characterize female population at fertile age and to identify reproductive and marital patterns and evaluate access to health services in Brazil ${ }^{8}$.

In this study, 15,575 women aged 15 to 49 were eligible for probing and answered a questionnaire regarding fertility, abstinence, pregnancy, labor, marital status, sexuality and contraception. Among these, 2,488 were adolescents aged from 15 to 19. Field research involved trained interviewers and supervision in collect data process. Reliability measurements were not showed.

For this study, sexually active adolescents who had had sexual intercourse in the last 12 months, and might had had the need of contraception, according to the criteria of PNDS-2006 were selected. Therefore, 1,227 adolescents who had not had sexual intercourse, 82 who had not had sexual intercourse in the past 12 months, 172 who were pregnant or wished to become pregnant in the upcoming 12 months were excluded, having selected a total of 1,007 adolescents. The outcome of the study was the present use of contraceptives. Due to the absence of such information on 21 adolescents, the final studied population was of 986 .

Among the variables of PNDS-2006, the ones described as important for the outcome $e^{9,10}$ were selected for analysis. The variables related to social-demographic characteristics selected were: household income, schooling, mother's schooling, work, age, race/etnicity, marital status, zone and region of residence. In the PNDS survey for the variable "marital status", the interviewees were asked: "Are you currently married or cohabiting with a partner?" In the present study, this variable admitted two answers: married or cohabiting couple, which only included cohabitation with a man, or unmarried.

The variables related to sexual and reproductive lives were age at first sexual intercourse, pregnancy history, number of living born children, use of contraception at first intercourse, age difference between partners and partner's schooling. The variables regarding the access and use of 
the health services (HS) were having received information on family planning (FP) during home visit by social health agent, having received information of FP in health services in the previous 6 months and having had accessibility of transportation to arrive at health center service (HS)

Variables related to schooling (having incomplete Junior High School or having complete Junior High School or further), household income per capita (up to US $\$ 81,39$ or $>$ than US $\$ 81,39$ ) and access to health services were considered expressions of adolescent vulnerability context ${ }^{11}$.

\section{Statistical Analysis}

Data analysis was performed using SPSS program, version 15, (SPSS Inc. Chicago, USA). The analysis procedures used sampling weight calibration and information on complex sampling plan $^{12}$.

At first, descriptive analysis of social-demographic, sexual and reproductive lives and access and use of health services was performed. Following prevalence of present use of contraceptive methods according to the type of method and the proportion of each method according to the marital status was described. The variables presenting coefficient of variation $(\mathrm{CV})$ superior to 0.30 were excluded from the analysis due to the low precision of their estimates.

Bivariate analysis between outcome and each independent variable using prevalence ratios and 95\% confidence intervals (95\% CI) was performed. Variables in which the bivariate Pearson's Chisquared tests presented a significance level lower than 0.25 were selected for multivariate modeling. Unconditional multivariate logistic regression, using the backward stepwise method as selection procedure of variables ${ }^{13}$ and removal criterion of $\mathrm{P}>$ 0,05 (Two-sided Wald test) was performed . Adjusted odds ratios (aOR) were estimated with their respective 95\% CI. Variables with more than $10 \%$ missing values were not included in the multivariate logistic regression.

The Ethics Research Committee of Instituto Fernandes Figueira, Fundação Oswaldo Cruz, approved the research project.

\section{Results}

Half of the adolescents lived in families with household income per capita lower than US \$ 81,39 . The greater part had completed junior high school (73.3\%) and was out of the working mar- ket $(76.9 \%)$. The majority were 18 or more years old $(60.3 \%)$, considered black / mulatto / yellow / Indian (65.0\%) and single (58.0\%). Only 39.1\% of adolescent mothers' had completed junior high school (information available for 449 adolescents) (Table 1).

The majority of adolescents had their first intercourse after age 15 (70.3\%) (Table 2). Approximately a third had had a pregnancy and $32.0 \%$ had had a living born child. The frequency of contraceptive use at first intercourse was $80.3 \%$.

The analysis of partners characteristics revealed that the majority was 5 or more years older $(55.9 \%)$ having completed junior high school (52.1\%) (Information available only for 393 and 378 adolescents, respectively).

Table 1. Social demographic characteristics of adolescents from National Survey on Demography and Health of Women and Children - PNDS 2006- Brazil.

\begin{tabular}{|c|c|c|}
\hline & & $\%$ \\
\hline Household Income per capita(US\$) & $\mathrm{n}=719$ & \\
\hline Up to US $\$ 81,39$ & & 48.3 \\
\hline$>$ than US\$ 81,39 & & 51.7 \\
\hline Schooling & $\mathrm{n}=983$ & \\
\hline Incomplete Junior High School & & 26.7 \\
\hline Complete Junior High School or further & & 73.3 \\
\hline Mother's Schooling ${ }^{*}$ & $\mathrm{n}=449$ & \\
\hline Incomplete Junior High School & & 60.9 \\
\hline Complete Junior High School or further & & 39.1 \\
\hline Work & $\mathrm{n}=986$ & \\
\hline Yes & & 23.1 \\
\hline No & & 76.9 \\
\hline Age & $\mathrm{n}=986$ & \\
\hline $15-17$ years & & 39.7 \\
\hline 18-19 years & & 60.3 \\
\hline Race/etnicity & $\mathrm{n}=979$ & \\
\hline White & & 35.0 \\
\hline Others (Black/Mulatto/Yellow/Indian) & & 65.0 \\
\hline Conjugal relationship & $\mathrm{n}=986$ & \\
\hline Married or cohabiting couples & & 42.0 \\
\hline Single & & 58.0 \\
\hline Area of residence & $\mathrm{n}=986$ & \\
\hline Urban & & 81.8 \\
\hline Rural & & 18.2 \\
\hline Region of residence & $\mathrm{n}=986$ & \\
\hline North & & 10.3 \\
\hline Northeast & & 26.3 \\
\hline Southeast & & 41.0 \\
\hline South & & 15.6 \\
\hline Center-west & & 6.8 \\
\hline
\end{tabular}

Source: National Survey on Demography and Health of Women and Children - PNDS 2006 Brazil (Ministry of Health, 2008).

${ }^{*} \mathrm{CV}$ superior to $15 \%$. Other CVs inferior to $15 \%$ 
Table 2. Sexual, reproductive characteristics and access/use of health services of adolescents from National Survey on Demography and Health of Women and Children - PNDS 2006- Brazil.

\begin{tabular}{|c|c|c|}
\hline & & $\%$ \\
\hline Age at first sexual intercourse & $\mathrm{n}=985$ & \\
\hline$<15$ years & & 29.7 \\
\hline$\geq 15$ years & & 70.3 \\
\hline Number of Pregnancies & $\mathrm{n}=986$ & \\
\hline None & & 64.8 \\
\hline 1 or more & & 35.2 \\
\hline Living- Born children & $\mathrm{n}=986$ & \\
\hline None & & 68.0 \\
\hline 1 or more & & 32.0 \\
\hline Method at first intercourse & $\mathrm{n}=975$ & \\
\hline Yes & & 80.3 \\
\hline No & & 19.7 \\
\hline Age difference between partners ${ }^{*}$ & $\mathrm{n}=393$ & \\
\hline Up to 4 years & & 44.1 \\
\hline 5 or more years & & 55.9 \\
\hline Partner's schooling* & $\mathrm{n}=378$ & \\
\hline Incomplete Junior High School & & 47.9 \\
\hline Complete Junior High School or further & & 52.1 \\
\hline Health agents visit ( discussed FP) & $\mathrm{n}=984$ & \\
\hline Yes & & 17.3 \\
\hline No & & 82.7 \\
\hline Information on FP at health service & $\mathrm{n}=984$ & \\
\hline Yes & & 9.7 \\
\hline No & & 90.3 \\
\hline \multicolumn{3}{|c|}{ Difficulty of transportation towards the HS $\mathrm{n}=986$} \\
\hline Yes & & 36.4 \\
\hline No & & 63.6 \\
\hline
\end{tabular}

Source: National Survey on Demography and Health of Women and Children - PNDS 2006 Brazil (Ministry of Health, 2008)

* Information available only for adolescents who are presently married. All CVs are below $15 \%$.

In regards to use and access to health services, $17.3 \%$ of the adolescents reported having received a visit of a social health agent and having discussed family planning (FP) in the last 12 months whereas only $9.7 \%$ had obtained information on FP in health services in the last 6 months (Table 2).

The use of contraceptives at the moment of inquiries reached a prevalence of $78.8 \%$ (CI 95\% 70.7-80.5). The most used methods were the male condom (51.6\%) and the pill (49.2\%). There was an inversion on the profile of use according to marital status. The majority of married adolescents or cohabiting couples used the pill (58.3\%), whereas the single ones used predominantly the male condom (65.5\%).
The results of bivariate analysis are described on Table 3. According to the defined criteria for statistical analysis, the following variables were selected for logistic regression modelling: adolescent schooling, race/etnicity, marital status, use of contraceptives at first sexual intercourse, information on FP in the last 6 months, and difficulty to access transportation to the HS. The household income per capita was excluded from the analysis due to the high percentage of ignored information as were variables related to partners for whom information was obtained only regarding married adolescents.

The multivariate analysis identified four factor associated to present use of contraceptives: having completed junior high school ( $\mathrm{p}=0.03$; $\mathrm{aOR}=2.29$; CI 95\% $1.07-4.85)$; being married or cohabiting with a partner $(\mathrm{p}<0.01 ; \mathrm{aOR}=$ 2.85; CI 95\% [1.45 - 5.59]); having used any contraceptive method at first sexual intercourse $(\mathrm{p}<$ 0.01 ; aOR = 2.77; CI 95\% 1.36 - 5.63); and having had access to means of transportation to arrive at the $\mathrm{HS}(\mathrm{p}<0.01 ; \mathrm{aOR}=3.33$; CI 95\% 1.42 - 7.80) (Table 4). Interactions among those factors were not observed. The accuracy of the model to predict the observed outcome was $80.4 \%$.

\section{Discussion}

The prevalence of the use of contraceptive methods among sexually active adolescents was $78.8 \%$ in the present study. Therefore, $21.2 \%$ were not using any contraceptive method and corresponded to a portion of sexually active adolescents with unmet desires regarding contraceptive methods.

Comparing results found here to others requires caution because place, country, population, age group and methodology are distinct. Brazilian researches of national ${ }^{3}$ and local scope ${ }^{14,15}$ developed in the 2000s identified percentages regarding the use of methods varying from $56 \%$ to $89 \%$. The highest percentages were observed among students and in groups with higher ages.

Researches as PNDS-2006, performed with data from Demographics and Health Surveys (DHS) allow more comparability because they are part of a project called MEASURE (Monitoring and Evaluation to Assess and Use Results) ${ }^{16,17}$. The study of Blanc et al. ${ }^{16}$ with data from 40 developing countries showed very diverse prevalence for sexually active adolescents. Colombia was distinguished with the highest prevalence (67.6\%), followed by Peru and Brazil. In Africa, countries showed lower prev- 
alence in the use of contraceptive methods, being the lowest found in Ethiopia (5.9\%).

In 1996, the United States presented a nonuse of contraceptive methods rate of $20 \%$ among adolescents in risk of unplanned pregnancies, whereas Sweden presented a rate of $4 \%$ and England $7 \%{ }^{18}$. More recently, in 2009, greater variations were related with the highest rate of nonuse in Poland $(26.7 \%)$ and the lowest in the Netherlands $(6.7 \%)^{19}$.
A tendency towards the increased use of contraception by adolescents was observed internationally between 1991 and $2003^{20}$, which can also be said for Brazil between 1996 and 20067,21. Social and cultural changes inflicted upon the family, cross generation and gender relationships, debate over sexuality in adolescence and advances in the fields of sexual and reproductive rights might have contributed for such changes.

Table 3. Crude prevalence (CI95\%) of the use of contraceptive methods according to the following characteristics of sexually active adolescents: social demographic, sexual and reproductive and contraceptive practices -PNDS 2006- Brazil.

\begin{tabular}{|c|c|c|c|c|c|c|c|c|}
\hline & $\mathbf{N}$ & & $\mathbf{N}$ & $\begin{array}{c}\text { Use } \\
\%\end{array}$ & $\begin{array}{c}\text { Non use } \\
\%\end{array}$ & $\begin{array}{l}\text { Crude } \\
\text { PR }\end{array}$ & CI $(95 \%)$ & $\mathbf{P}$ \\
\hline Studied population & 986 & & & 78.8 & 21.2 & - & - & - \\
\hline \multirow{2}{*}{$\begin{array}{l}\text { Household income per } \\
\text { capita (US\$) }\end{array}$} & \multirow[t]{2}{*}{719} & Up to US\$ 81.39 & 354 & 69.0 & 31.0 & 1 & & \\
\hline & & $>$ than US\$ 81.39 & 365 & 88.1 & 11.9 & 1.28 & $(1.00-1.63)$ & $<0.01$ \\
\hline \multirow[t]{2}{*}{ Schooling } & \multirow[t]{2}{*}{983} & Incomplete Junior High School & 326 & 68.3 & 31.7 & 1 & & \\
\hline & & Complete Junior High School or further & 657 & 82.5 & 17.5 & 1.21 & $(0.99-1.47)$ & 0.06 \\
\hline \multirow[t]{2}{*}{ Work } & \multirow[t]{2}{*}{986} & Yes & 286 & 83.3 & 16.7 & 1.08 & $(0.93-1.23)$ & 0.27 \\
\hline & & No & 700 & 77.4 & 22.6 & 1 & & \\
\hline \multirow[t]{2}{*}{ Age } & \multirow[t]{2}{*}{986} & 15 to 17 years & 436 & 78.4 & 21.6 & 1 & & \\
\hline & & 18 to 19 years & 550 & 79.0 & 21.0 & 1.01 & $(0.85-1.20)$ & 0.92 \\
\hline \multirow[t]{2}{*}{ Color } & \multirow[t]{2}{*}{979} & White & 350 & 85.7 & 14.3 & 1.15 & $(0.98-1.34)$ & 0.05 \\
\hline & & Black or mulatto / others & 629 & 74.7 & 25.3 & 1 & & \\
\hline \multirow[t]{2}{*}{ Marital status } & \multirow[t]{2}{*}{986} & Married & 393 & 84.9 & 15.1 & 1.14 & $(0.96-1.35)$ & 0.07 \\
\hline & & Not married & 593 & 74.4 & 25.6 & 1 & & \\
\hline \multirow[t]{2}{*}{ Zone of residence } & \multirow[t]{2}{*}{986} & Urban & 694 & 78.0 & 22.0 & 0.95 & $(0.82-1.09)$ & 0.44 \\
\hline & & Rural & 292 & 82.4 & 17.6 & 1 & & \\
\hline \multirow[t]{5}{*}{ Region of residence } & \multirow[t]{5}{*}{986} & North & 220 & 74.3 & 25.7 & 1 & & \\
\hline & & Northeast & 183 & 83.8 & 16.2 & 1.13 & $(0.97-1.31)$ & 0.09 \\
\hline & & South & 214 & 84.0 & 16.0 & 1.13 & $(0.97-1.32)$ & 0.11 \\
\hline & & Southeast ${ }^{\S}$ & 176 & 74.5 & 25.5 & 1.00 & $(0.78-1.29)$ & 0.97 \\
\hline & & Center-west & 193 & 79.7 & 20.3 & 1.07 & $(0.91-1.26)$ & 0.37 \\
\hline \multirow[t]{2}{*}{ Age at first intercourse } & \multirow[t]{2}{*}{985} & $<15$ years & 304 & 75.1 & 24.9 & 1 & & \\
\hline & & $\geq 15$ years & 681 & 80.3 & 19.7 & 1.26 & $(0.67-2.37)$ & 0.46 \\
\hline \multirow[t]{2}{*}{ Pregnancies } & \multirow[t]{2}{*}{986} & None & 644 & 78.4 & 21.6 & 0.99 & $(0.83-1.17)$ & 0.86 \\
\hline & & One or more & 342 & 79.5 & 20.5 & 1 & & \\
\hline \multirow[t]{2}{*}{ Living Born children } & \multirow[t]{2}{*}{986} & None & 676 & 78.7 & 21.3 & 1.00 & $(0.83-1.18)$ & 0.96 \\
\hline & & One or more & 310 & 79.0 & 21.0 & 1 & & \\
\hline \multirow{2}{*}{$\begin{array}{l}\text { Use of method at first } \\
\text { intercourse }\end{array}$} & \multirow[t]{2}{*}{975} & Yes & 771 & 82.4 & 17.6 & 1.28 & $(1.05-1.56)$ & 0.01 \\
\hline & & No & 204 & 64.5 & 35.5 & 1 & & \\
\hline \multirow{2}{*}{$\begin{array}{l}\text { Age difference between } \\
\text { partners* }\end{array}$} & 393 & Up to 4 years & 168 & 90.4 & 9.6 & 1.12 & $(0.99-1.26)$ & 0.05 \\
\hline & & $>5$ years & 225 & 80.6 & 19.4 & 1 & & \\
\hline Partner's schooling ${ }^{*}$ & 378 & Incomplete Junior High School & 174 & 79.2 & 20.8 & 1 & & \\
\hline & & Complete Junior High School or further & 204 & 89.8 & 10.2 & 1.13 & $(0.99-1.30)$ & 0.04 \\
\hline Visit of health agent/ & 984 & Yes & 168 & 79.0 & 21.0 & 1.00 & $(0.84-1.19)$ & 0.96 \\
\hline discussed FP & & No & 816 & 78.7 & 21.3 & 1 & & \\
\hline Information on $\mathrm{FP}$ & 984 & Yes & 276 & 86.9 & 13.1 & 1.14 & $(0.99-1.31)$ & 0.05 \\
\hline & & No & 708 & 76.2 & 23.8 & 1 & & \\
\hline Difficulty of Access to & 986 & Yes & 320 & 66.0 & 34.0 & 1 & & \\
\hline transportation to HS & & No & 666 & 86.1 & 13.9 & 1.30 & $(1.02-1.67)$ & $<0.01$ \\
\hline
\end{tabular}

Source: National Survey on Demography and Health of Women and Children - PNDS 2006 Brazil (Ministry of Health, 2008)

${ }^{\S} \mathrm{CV}=32 \%$ was maintained so that description of all Brazilian regions was possible. 
Table 4. Association between the use of contraceptive methods among sexually active adolescents and potential social demographic, sexual and reproductive, and contraceptive practices, Brazil.

\begin{tabular}{|c|c|c|c|c|c|c|}
\hline & $\begin{array}{c}\text { Ajus } \\
\text { OR }\end{array}$ & CI 95\% & $\mathbf{p}$ & Ajus OR & CI 95\% & $\mathbf{p}$ \\
\hline \multicolumn{7}{|l|}{ Schooling } \\
\hline Incomplete Junior High School & 1 & & & & & \\
\hline Complete Junior High School or further & 2,17 & $(1,03-4,55)$ & 0,03 & 2,29 & $(1,07-4,85)$ & 0.03 \\
\hline \multicolumn{7}{|l|}{ Race/etnicity } \\
\hline White & 1,65 & $(0,84-3,24)$ & 0,14 & - & - & - \\
\hline Others (Black/mulatto/yellow/indían) & 1 & & & & & \\
\hline \multicolumn{7}{|l|}{ Conjugal relationship } \\
\hline Married or cohabiting couples & 2,84 & $(1,45-5,54)$ & $<0.01$ & 2,85 & $(1,45-5,59)$ & $<0.01$ \\
\hline Not married & 1 & & & & & \\
\hline \multicolumn{7}{|l|}{ Use of method at first intercourse } \\
\hline Yes & 2,72 & $(1,37-5,42)$ & $<0.01$ & 2,77 & $(1,36-5,63)$ & $<0.01$ \\
\hline No & 1 & & & & & \\
\hline \multicolumn{7}{|l|}{ Information on FP } \\
\hline Yes & 1,72 & $(0,82-3,81)$ & 0,14 & - & - & \\
\hline No & 1 & & & & & \\
\hline \multicolumn{7}{|l|}{ Difficulty of access to transportation to HS } \\
\hline Yes & 1 & & & & & \\
\hline No & 2,90 & $(1,32-6,36)$ & $<0.01$ & 3,33 & $(1,42-7,80)$ & $<0.01$ \\
\hline
\end{tabular}

Source: National Survey on Demography and Health of Women and Children - PNDS 2006 Brazil (Ministry of Health, 2008)

Data from PNDS-2006 showed the pill and the male condom as the most adopted methods by Brazilian adolescents. In countries of Africa, Asia and Latin America the pill and injectable hormones were the prevailing methods adopted by adolescents ${ }^{16,17}$. In a study of 24 European countries, Godeau observed use of male condom followed by double protection prevalent ${ }^{19}$.

The comparison between data from PNDS1996 to PNDS-2006 reveals a significant increase in the use of male condom in Brazil considering all adolescents aged 15 to 19 - from 3.3\% in 1996 to $13.9 \%$ in 2006 , which was the tendency-observed in other countries ${ }^{17,20}$. This might reflex the impact of governmental actions as well as other segments of society, distributing condoms for the Brazilian population in efforts to prevent HIV/AIDS.

Factors associated to the use of contraceptive methods identified in this study such as schooling, marital status, and contraception at first intercourse are widely known. The association between higher levels of schooling, higher use of contraceptive methods and less incidence of pregnancy in adolescence has been well documented in literature ${ }^{3,9,22}$.

The association between being married or cohabiting with a partner and higher use of contraceptive methods found in here corresponds to what has been reported in the Brazilian PNDS-1996.
However, in 2009, Blanc et al. ${ }^{16}$ found an inverse association studying 40 countries from Latin America, Asia and Africa, with higher differences for the African countries. The same was evidenced in Sub-Saharan Africa in 2006 ${ }^{17}$. Inequalities in gender relationships are pointed out as factors that hinder the debate about family planning among spouses, which reverberates in the contraceptive practices of couples in African countries ${ }^{23}$.

The role of matrimonial adoption and contraceptive practices does not seem to be linear. Possibly the negotiation terms of contraception between partners are influenced by socio-cultural aspects such as economy, gender and class, among others. In some social and relational contexts, a stable relationship might make the use of contraceptives easier, whereas in others it may work as a barrier for both the prevention of unexpected pregnancies as well as the protection against STDs/AIDS.

A positive association between the use of contraceptive methods at first intercourse and the present use of contraceptive methods was found in other studies, reinforcing the idea that the first sexual intercourse sets a boundary and influences future contraceptive practices ${ }^{7,9,24}$. We should highlight that schooling also interferes in the adoption of contraceptive methods at the first sexual intercourse ${ }^{10}$. 
Among adolescents, the motivation towards the debate and reflection on sexuality should happen before sexual initiation, in different settings, particularly in schools and health services. However, health services have been prioritizing contraception in regards to family planning, among adolescents who have already initiated their reproductive lives ${ }^{25}$.

An important finding of the present research is the associating between accessibility to transportation towards the health service and adoption of contraceptive methods. $36.4 \%$ adolescents of the studied sample referred having had transportation difficulties to HS, which may explain, in part the low frequency of information regarding FP in the same services (9.7\%).

Brazilian studies on contraceptive practices among Brazilian adolescents and their relationships towards health services, in the scope of healthcare, have been few $^{3}$.Accessibility entails several components as quality, care and regionalization of rendered services, among others. The availability of services near the patients residence, ease of delivery and accompaniment of contraceptive methods use, have been considered guiding elements in the evaluation of reproductive planning services quality ${ }^{26}$. Amid pregnant adolescents, those who attended health services before pregnancy, referred more frequently to the adoption of contraceptive methods ${ }^{27}$.

The difficult access to health services expresses social vulnerability and has repercussions on the healthcare of adolescents. In a study with adolescents living in poor communities in Rio de Janeiro, Taquette ${ }^{28}$ found that the difficulty in accessing health services was present due to lack of services near the residence or because of racial discrimination perpetrated by health professionals. They also identified that adolescents from private schools had more ease in getting their demands met at the first public service that they went to ${ }^{6}$.

Prejudice and unpreparedness of health professionals in dealing with issues related to sexuality, have become obstacles to the use of health services by the adolescent population ${ }^{29}$, probably due to the poor understanding of adolescents rights and legal and ethical aspects such as secrecy, privacy, and discriminatory relations of power in healthcare assistance, values, knowledge and personal professional aspects ${ }^{25}$. In the present study, 54\% of the adolescents declared they feared not to be assisted in the health services (data not shown).

Access to information and schooling (discussed from the level of schooling), and the material and social availability of resources (evalu- ated through the ease of transportation to the health service) are important components to evaluate social vulnerability ${ }^{11}$. Therefore, the present study points to the underlying presence of social vulnerability components associated or not to the use of contraceptive methods.

Although logistic regression applied when the outcome with a high prevalence of outcome overestimated the prevalence ratio, OR was appropriate to identify what conditions were associated to the use of contraceptive methods, that was the aim of this study,

The restricted accessibility to information on mother's schooling, household income, and information on partners of married adolescents could be considered limitations of the present study. The inclusion of such information in future inquiries, independently of the marital status, might contribute to the definition of specific strategies.

The results of the present work might be generalized for the Brazilian adolescent population, aged 15 to 19 who are sexually active, in need of contraception. That is so due to the use of a random sample of national scope. The findings of this study could possibly be applied to other developing countries. Moreover, these factors could be investigated in other countries through data from MEASURE DHS, because the PNDS adopts a similar methodology for the performance of inquiries.

The issue of reproductive health among adolescents should be thought of more globally, establishing intersectorial articulations with other public policies, so that society and its institutions might be able to deal positively with adolescent sexuality, facing issues of vulnerability and favoring their well-being and development. Strategies on extending access and use of health services, alongside with other intersectorial policies focused on adolescents, should strengthen and ensure their sexual and reproductive rights.

\section{Collaborations}

R Rozenberg, EG Ramos, C Bonan and KS Silva participated equally in all stages of preparation of the article. 


\section{Referências}

1. The World Bank [internet homepage]. Population total [cited 2012 Jan 24]. Available from: http:// data.worldbank.org/country/brazil

2. Paim J, Travassos C, Almeida C, Bahia L, Macinko J. The Brazilian health system: history, advances, and challenges. Lancet 2011; 377(9779):1778-1797.

3. Heilborn ML, Aquino EML, Bozon M, Knauth DR, organizadores. O aprendizado da sexualidade: reprodução e trajetórias sociais de jovens brasileiros. Rio de Janeiro: Editora Garamond, Editora Fiocruz; 2006.

4. Marinho LB, Aquino EML, Almeida MCC. Práticas contraceptivas e iniciação sexual entre jovens de três capitais brasileiras. Cad Saude Publica 2009; 25(Supl. 1):S227-S239.

5. Alves CA, Brandão ER. Vulnerabilidades no uso de métodos contraceptivos entre adolescentes e jovens: interseções entre políticas públicas e atenção à saúde. Cien Saude Colet 2009; 14(2):661-670.

6. Claro LBL, March C, Mascarenhas MTM, Castro IAB, Rosa MLG. Adolescentes e suas relações com serviços de saúde: estudo transversal em escolares de Niterói, Rio de Janeiro, Brasil. Cad Saude Publica 2006; 22(8):1565-1574

7. Brasil. Ministério da Saúde (MS). PNDS-2006 Pesquisa nacional de demografia e saúde da criança e da mulher. Brasília, DF: MS; 2008.

8. Berquó E. Sobre o sistema internacional de pesquisas em demografia e saúde reprodutiva. Rev Bras Epidemiol 2008; 11(Supl. 1):72-89.

9. Longo LAF. Juventude e contracepção: um estudo dos fatores que influenciam o comportamento contraceptivo das jovens brasileiras de 15 a 24 anos. Revista Brasileira de Estudos da População 2002; 19(2): 229-247.

10. Barros RCR. Fatores envolvidos na adesão das adolescentes aos métodos contraceptivos. In: Monteiro D, Trajano A, Bastos A, organizadores. Gravidez e Adolescência. Rio de Janeiro: Editora Revinter; 2009. p. 295-300.

11. Ayres JRCM, França-Júnior I, Calazans GJ, SalettiFilho HC. O conceito de vulnerabilidade e as práticas de saúde: novas perspectivas e desafios. In: Czeresnia D, Freitas CM, organizadores. Promoção da saúde: conceitos, reflexões, tendências. Rio de Janeiro: Editora Fiocruz; 2009. p.121-144.

12. Szwarcwald CL, Damacena GN. Amostras complexas em inquéritos populacionais: planejamento e implicações na análise estatística dos dados. Rev Bras Epidemiol 2008; 11(Supl. 1):38-45.

13. Kleinbaum DG, Klein M. Logistic Regression A SelfLearning Text. New York: Springer; 2010.

14. Castro MG, Abramovay M, Silva LB, organizadores. Juventudes e sexualidade. Brasília: Unesco; 2004.

15. Rocha CLA, Horta B, Pinheiro RT, Cruzeiro ALS, Cruz S. Use of contraceptive methods by sexually active teenagers in Pelotas, Rio Grande do Sul State, Brazil. Cad Saude Publica 2007; 23(12):2862-2868.

16. Blanc AK, Tsui AO, Croft TN, Trevitt JL. Patterns and Trends in Adolescents' Contraceptive use and discontinuation in developing countries and comparisons with adult women. Int Perspect Sex Reprod Health 2009; 35(2):63-71.
17. Cleland J, Ali MM, Shah I. Trends in protective behavior among single vs. married young women in Sub-Saharan Africa: The big picture. Reprod Health Matters 2006; 14(28):17-22.

18. Darroch JE, Singh S, Forst JJ. Differences in teenage pregnancy rates among five developed countries: the roles of sexual activity and contraceptive use. Fam Plann Perpect 2001; 33:244-250.

19. Godeau E, Gabhainn SN, Vignes C, Ross J, Boyce W, Todd J. Contraceptive Use by 15 -Year-Old Students at Their Last Sexual Intercourse. Arch Pediatr Adolesc Med 2008; 162:66-73.

20. Anderson JE, Santelli JS, Morrow B. Trends in adolescent contraceptive use, unprotected and poorly protected sex, 1991-2003. J Adolesc Health 2006; 38: 734-739.

21. Sociedade Civil Bem-Estar Familiar no Brasil (Bemfam). Programa de Pesquisas de Demografia e Saúde (DHS), Macro Internacional. Pesquisa Nacional sobre Demografia e Saúde 1996. Rio de Janeiro: Bemfam; 1997.

22. Gomes KRO, Speizer IS, Oliveira DCO, Moura LNB, Gomes FM. Contraceptive Method Use by Adolescents in Brazilian State Capital. J Pediatr Adolesc Gynecol 2008; 21(4):213-219.

23. Pullum T, Cleland J, Shah I. Consensus, Power and Trust in the Use of Family Planning and Condoms by Couples in Eastern and Southern Africa. In: XXV International Population Conference of the International Union for the Scientific Study of Population; 2005; Tours, France. p. 1-33

24. Delva W, Wuillaume F, Vansteelandt S, Claeys P, Verstraelen H, Temmerman M. Sexual behaviour and contraceptive use among youth in the Balkans. Eur J Contracept Reprod Health Care 2007; 12(4):309-315.

25. Brasil. Ministério da Saúde (MS). Marco teórico e referencial: saúde sexual e saúde reprodutiva de adolescentes e jovens. Brasília: MS; 2007.

26. Moura ER, Silva RM, Galvão MTG. Dinâmica do atendimento em planejamento familiar no programa Saúde da Família no Brasil. Cad Saude Publica 2007; 23(4):961-970.

27. Brandão ER. Desafios da contracepção juvenil: interseções entre gênero, sexualidade e saúde. Cien Saude Colet 2009; 14(4):1063-1071.

28. Taquette SR. Aids e juventude: gênero, classe e raça. Rio de Janeiro: EdUERJ; 2009.

29. Osis MJD, Faúndes A, Makuch MY, Mello MB, Souza $\mathrm{MH}$, Araújo MJO. Atenção ao planejamento familiar no Brasil hoje: reflexões sobre os resultados de uma pesquisa. Cad Saude Publica 2006; 22(11):24812490.

Artigo apresentado em 24/06/2012

Aprovado em 31/07/2012

Versão final apresentada em 23/08/2012 